University of Nebraska - Lincoln

DigitalCommons@University of Nebraska - Lincoln

Publications from USDA-ARS / UNL Faculty

U.S. Department of Agriculture: Agricultural

Research Service, Lincoln, Nebraska

November 1994

\title{
Irrigation and Culm Contribution to Yield and Yield Components of Winter Wheat
}

Gregory S. McMaster

USDA-ARS, greg.mcmaster@ars.usda.gov

Wallace Wilhelm

University of Nebraska-Lincoln, wwilhelm1@unl.edu

Patricia N. S. Bartling

USDA-ARS, pat.bartling@ars.usda.gov

Follow this and additional works at: https://digitalcommons.unl.edu/usdaarsfacpub

Part of the Agricultural Science Commons

McMaster, Gregory S.; Wilhelm, Wallace; and Bartling, Patricia N. S., "Irrigation and Culm Contribution to Yield and Yield Components of Winter Wheat" (1994). Publications from USDA-ARS / UNL Faculty. 86. https://digitalcommons.unl.edu/usdaarsfacpub/86

This Article is brought to you for free and open access by the U.S. Department of Agriculture: Agricultural Research Service, Lincoln, Nebraska at DigitalCommons@University of Nebraska - Lincoln. It has been accepted for inclusion in Publications from USDA-ARS / UNL Faculty by an authorized administrator of DigitalCommons@University of Nebraska - Lincoln. 


\title{
Irrigation and Culm Contribution to Yield and Yield Components of Winter Wheat
}

\author{
Gregory S. McMaster, * Wallace W. Wilhelm, and Patricia N. S. Bartling
}

\begin{abstract}
Water is generally the limiting factor in U.S. Great Plains wheat (Triticum aestivum L.) production. With increasing demands for limited water, improving the efficacy of irrigation is critical. One technique is to irrigate during responsive stages of crop development, but few studies have examined this approach. This 2-yr study on a Nunn clay loam soil (fine, montmorillonitic, mesic Aridic Argiustoll) was designed to examine the effects of irrigation, based on stage of crop development, on winter wheat yield, yield components (on a plant basis), and specific culm responses. In the first year, the treatments were control (dryland), and irrigation at late jointing. In the second year, the treatments were dryland, irrigation at late jointing, irrigation at anthesis, and irrigation at both late jointing and anthesis. Irrigation at late jointing or anthesis significantly increased grain yield and the most important yield component (spikes per plant), as well as spikelets per plant, number of kernels per plant, and kernel weight per plant. The increased spikes per plant in the irrigation treatments, particularly with late-jointing irrigation, was due to reduced tiller abortion. Increased yield was primarily due to the contribution of more secondary tillers (T10, T1, T20, T21, T30, and T31) that produced spikes. The contribution of main stems to the total yield decreased from $92 \%$ to at most $86 \%$ with irrigation, although the dry weight of main-stem spikes increased with irrigation. The contribution to total yield of the main yield-producing tillers, $\mathrm{T1}$ and $\mathrm{T} 2$, decreased from 20 to $15 \%$ and 19 to $15 \%$, respectively, with irrigation. As with main-stem spikes, irrigation also increased $\mathrm{T} 1$ and T2 spike dry weight. Therefore, the production of secondary spikes due to irrigation treatments was not at the expense of main stem or primary tiller spikes. If only one irrigation can be applied, irrigation at late jointing is recommended for central Great Plains conditions, due to its greater effect on tiller survival. This implies that developmental and physiological processes at late jointing are critical in determining final grain yield, and water stress should be avoided at this growth stage.
\end{abstract}

$\mathrm{W}$ ATER is a primary factor limiting winter wheat production and yield in the U.S. Great Plains (Unger and McCalla, 1980; Wilhelm et al., 1989), with rainfall being quite variable throughout the growing season and among years. There is increasing demand for limited water, the cost of water is rising, and water sources such as the Ogallala Aquifer are being depleted. These problems require maximizing the efficacy of irrigation practices.

Winter wheat is plastic in its responses to the timing of water availability. Many different developmental and physiological processes can affect the yield components that result in highly variable final yields. Increasing recognition that many developmental and physiological pro-

G.S. McMaster and P.N.S. Bartling, USDA-ARS, Great Plains Systems Res. P.O. Box E, Fort Collins, CO 80522; W.W. Wilhelm, USDA-ARS, Soil and Water Conservation Research, 119 Keim Hall, Univ. of Nebraska, Lincoln, NE 68583. Received 9 Aug. 1993. *Corresponding author.

Published in Agron. J. 86:1123-1127 (1994) cesses are involved in determining wheat yield has emphasized the importance of scheduling cultural practices such as fertilizer and herbicide applications with specific developmental stages of the crop. Success of spring irrigation on increasing winter wheat yield may be dependent on water application during specific developmental and physiological processes. Some developmental and physiological processes occurring at late jointing are leaf appearance and senescence, tiller abortion, internode growth, and floret primordium initiation and abortion (McMaster et al., 1992b), and irrigation at this time could affect any or all of these processes. Similarly, irrigation at anthesis could affect any of the processes of grain set and kernel and peduncle growth. Unfortunately, only a few studies (Eck, 1988; Musick and Dusek, 1980; Wilhelm et al., 1989) have examined winter wheat yield responses to water under field conditions in the Great Plains, and these studies reported few data on yield components.

A study was conducted to test the effects of spring irrigation on winter wheat development and growth and to determine critical growth stages that are most sensitive to water stress. This paper examines the final grain yield as influenced by various yield components, and documents the contribution of specific culms to yield in response to irrigation.

\section{MATERIALS AND METHODS}

\section{Experimental Design and Sampling Procedures}

A 2-yr study was conducted northeast of Fort Collins, $\mathrm{CO}$ at the Colorado State University Horticulture Farm $\left(41^{\circ} 30^{\prime} \mathrm{N}\right.$ lat, $105^{\circ} 5^{\prime} \mathrm{W}$ long) on a Nunn clay loam soil (Aridic Argiustoll). Soil tests at planting indicated that all nutrients were well above recommended levels, so no fertilizer was added. A hard red winter wheat (cv. Vona) was planted 17 Sept. 1986 and 23 Sept. 1987 , in $30-\mathrm{cm}$ row spacing. Plant density was determined at maturity by counting the number of plants in two $1-\mathrm{m}$ row segments.

Treatments in spring 1987 were dryland (D, no irrigation) and irrigation at late jointing (J) on 19 May, about Zadoks stage 33 (Zadoks et al., 1974). Yield component analyses are based on observations from three replications. Plot size was 3 by $30 \mathrm{~m}$ (10 rows)

In spring 1988, irrigation treatments were dryland (D), single irrigation at late jointing $(\mathrm{J})$ on 13 May or anthesis (A) on 6 June, and irrigation at both late jointing and anthesis $(\mathrm{J}+\mathrm{A})$. The 1988

Abbreviations: A, irrigated at anthesis; D, dryland; GPLR, glumes, paleas, lemmas, and rachis; J, irrigated at late jointing; $\mathrm{J}+\mathrm{A}$, irrigated at late jointing and anthesis; Ln, $n$th leaf (counted acropetally); MS, main stem; Tn, Tnn, Tnnn, etc., $n$th primary, secondary, tertiary tiller, etc. (where digit value represents tiller number and digit position represents tiller rank). 
experiment consisted of four blocks in a randomized complete block design. Plot size was 7.2 by $15 \mathrm{~m}$ ( 24 rows).

Gated pipes were used to apply water to furrows. Water was applied for 6 to $8 \mathrm{~h}$. After the entire plot had been flooded for $4 \mathrm{~h}$, water application was stopped and the furrows were allowed to drain. Based on neutron probe readings before and after irrigation, $\approx 65 \mathrm{~mm}$ of water was added to the soil profile by irrigation.

After maturity, plants from a $0.5-\mathrm{m}$ length of one row were collected in each plot (13 July 1987 and 15 July 1988). All individuals in this sample were arranged according to size (number and size of tillers and height of culms), and the central five plants were selected. From these plants, each culm was identified according to the morphological naming scheme of Klepper et al. (1983). Wire tags had been placed around main stem, $\mathrm{T} 1$, and $\mathrm{T} 2$ culms in late fall and late winter, to aid in identification of tillers at maturity. Successive leaves that appear on a culm are numbered acropetally, where the first true leaf is L1, followed by L2, L3, and so on. The first culm, appearing at emergence is the main stem (MS). Primary tillers are shoots that appear from the axil of main-stem leaves and are designated by $\mathrm{T}$ and a single-digit number. For example, the tiller appearing from the axil of $\mathbf{L l}$ on the MS is Tl. Secondary tillers appear from axils of leaves on primary tillers; secondary tillers are given two-digit designations. The first digit refers to the primary tiller from which the secondary tiller formed, and the second digit to the associated leaf of the primary tiller. Tiller T21 is a secondary tiller appearing from the axil of the first leaf of the primary tiller $\mathrm{T} 2$. The naming scheme continues for tertiary (e.g., T121) and quaternary (e.g., T1000) tillers.

Yield components (number of spikes, number of spikelets, kernel number, total kernel weight, rachis weight, and chaff weight comprised of glumes, paleas, lemmas, and rachillas) were measured for each morphologically identified culm. Plant material was dried at $65^{\circ} \mathrm{C}$ to constant weight. Grain yield was estimated after using a plot combine to collect the grain (four replications).

Soil water estimates were taken using neutron probe measurements. Readings in the top $1.8 \mathrm{~m}$ of soil were taken periodically in one sampling tube per replication, with four replications per treatment. No measurements were available for spring and summer 1988.

\section{Statistical Analysis}

The SAS statistical package (SAS, 1991) was used for data analysis. The MEANS procedure was used in aggregating spikelet position information to the spike level as well as for computing basic statistics. The general linear model procedure was used for analysis of variance with significant differences measured by least significant differences. A general linear model analysis showed no significant year $\times$ treatment interaction for grain yield (combine estimate) and plant yield components in the D and $\mathbf{J}$ irrigation treatments. Therefore, the $2 \mathrm{yr}$ of data were pooled for the $\mathrm{D}$ and $\mathrm{J}$ treatments, resulting in seven replicates for $\mathrm{D}$ and $J$ treatments (three from 1987 and four from 1988) and four replicates for A and J + A (all from 1988). The approach of sampling five median plants per plot eliminated the need for plant variability analysis, leaving treatment and block variability to be considered.

A significant year $\times$ treatment interaction was found in 1988 for average kernel weight; therefore, the influence of the $A$ and $\mathrm{J}+\mathrm{A}$ vs. D and J contrast was calculated.

The contribution of tiller classes (e.g., primary tillers, secondary tillers) and specific culms to total plant yield was determined by dividing the tiller class or specific culm yield for a treatment by the total plant weight for a treatment. The main stem was included with the primary tillers class.
The univariate procedure was used to analyze the precipitation data. Both years of the experiment were within a rank of the 10 closest years to the long-term average precipitation.

\section{RESULTS AND DISCUSSION}

The observed temperature and precipitation for both years of the experiment did not deviate significantly from 30-yr normals (Table 1). In 1986-1987, the fall and spring tended to be slightly cooler and wetter than normal, with late spring and early summer slightly warmer and dryer than normal. In 1987-1988, generally the entire growing season was slightly cooler and dryer than normal. Limited measures of total soil water content indicated 28,47 , and $24 \mathrm{~mm}$ less water (to a depth of $183 \mathrm{~cm}$ ) in the D than the J treatments on 28 May, 4 June, and 9 July 1987, respectively.

Water often limits yield in the Great Plains (Eck, 1988; Musick and Dusek, 1980), so it was not surprising that in both years irrigation significantly increased grain yield above that of the dryland treatment (Table 2). Late-jointing irrigation and irrigation at anthesis significantly increased yield by only $\approx 20 \%$ compared with the dryland treatment. As expected, the J $+A$ treatment produced the highest yield (analysis not shown).

In a similar experiment at Bushland, TX, Eck (1988) found that irrigation at tillering and jointing resulted in higher yields than irrigation at heading and anthesis. Eck (1988) concluded that jointing is the best time to irrigate, because there is greater probability of receiving significant rainfall during heading and anthesis than during jointing, and with irrigation at jointing there remains potential for high yields if precipitation occurs during subsequent

Table 1. Climatological data from a Class A weather station located at the Colorado State University Horticulture Farm.

\begin{tabular}{|c|c|c|c|c|c|}
\hline \multirow[b]{2}{*}{ Year } & \multirow[b]{2}{*}{ Month } & \multicolumn{2}{|c|}{ Monthly temperature } & \multicolumn{2}{|c|}{ Monthly precipitation } \\
\hline & & Observed $\dagger$ & Departure $\ddagger$ & Observed & Departure $\ddagger$ \\
\hline & & & $\mathrm{C}-$ & $-m$ & $\mathrm{~m}-$ \\
\hline \multirow[t]{11}{*}{$1986-1987$} & Sept. & 13.7 & -1.9 & 31 & -3 \\
\hline & Oct. & 8.8 & -0.8 & 40 & 12 \\
\hline & Nov. & 1.9 & -0.8 & 39 & 24 \\
\hline & Dec. & -2.4 & -0.4 & 7 & -6 \\
\hline & Jan. & -1.0 & 1.7 & 10 & 1 \\
\hline & Feb. & -0.1 & 0.8 & 33 & 21 \\
\hline & Mar. & 2.4 & -0.2 & 59 & 32 \\
\hline & Apr. & 9.2 & 1.2 & 10 & -40 \\
\hline & May & 13.4 & 0.3 & 101 & 29 \\
\hline & June & 18.4 & 0.4 & 48 & 4 \\
\hline & July & 20.3 & -1.0 & 20 & -20 \\
\hline Mean/Total & & 7.7 & -0.1 & 398 & 54 \\
\hline \multirow[t]{12}{*}{$1987-1988$} & Aug. & 18.3 & -2.0 & 13 & -22 \\
\hline & Sept. & 14.1 & -1.4 & 11 & -23 \\
\hline & Oct. & 7.7 & -1.6 & 12 & -16 \\
\hline & Nov. & 1.9 & -0.8 & 32 & 18 \\
\hline & Dec. & -4.1 & -2.2 & 10 & -3 \\
\hline & Jan. & -6.2 & -3.4 & 3 & -6 \\
\hline & Feb. & -1.9 & -1.1 & 9 & -4 \\
\hline & Mar. & 1.6 & -0.9 & 32 & 5 \\
\hline & Apr. & 8.2 & 0.1 & 21 & -29 \\
\hline & May & 13.1 & 0.0 & 58 & -14 \\
\hline & June & 20.2 & 0.1 & 13 & -31 \\
\hline & July & 20.4 & -1.0 & 50 & 11 \\
\hline Mean/Total & & 7.8 & -1.0 & 264 & -114 \\
\hline
\end{tabular}

$\dagger$ Mean observed monthly temperature is based on daily maximum and minimum temperatures.

\$ Departures from normal represent the observed minus the 30-yr mean obtained from NOAA climatological records for Fort Collins, CO. 
Table 2. Combine-harvested wheat grain yields from four irrigation treatments.

\begin{tabular}{lc}
\hline Treatment & Grain yield \\
\hline & $\mathrm{g} \mathrm{m}^{-2}$ \\
Pooled over 1987 and 1988 & \\
\hline Dryland (control) & 396 \\
Irrigation at late jointing (J) & 474 \\
$\quad$ LSD (0.05) & 64 \\
1988 & \\
\hline Irrigation at anthesis (A) & 442 \\
Irrigation at J + A & 529 \\
$\quad$ LSD (0.05) & 53 \\
\hline
\end{tabular}

reproductive growth. Rainfall probabilities during various growth stages are similar in our experimental area (Table 1).

Detailed examination of the yield components helps elucidate why higher yields (and potentials) were observed. All grain yield components, except individual kernel weight, increased as irrigation was applied. Irrigation at jointing increased the number of spikes per plant, spikelet number per plant, number of kernels per plant, and chaff weight by $\approx 80 \%$ over dryland conditions (Table 3 ).

The effects of the $J$ irrigation on yield components can be better understood when considering the developmental sequence of the shoot apex. Jointing is the time when tiller appearance has stopped and tiller abortion begins to accelerate (Darwinkel, 1978; Kirby, 1985; McMaster et al., 1991), floret primordia initiation and differentiation of floret parts are occurring (Baker and Gallagher, 1983; Barnard, 1955; Fisher, 1973), and the flag leaf is appearing (Bauer et al., 1983; McMaster et al., 1992a). Irrigation at jointing should have the greatest effect on the yield components associated with these developmental events. Our data support this hypothesis, especially the response of the number of spikes per plant to irrigation. The change in number of kernels per plant was due primarily to more spikes per plant than to an increase in grain set within a spike, since the number of kernels per spike was not altered by irrigation (Table 3 ). The increased kernel weight per plant also was due to more spikes per plant, because the mean kernel weight was not affected by irrigation at jointing. The greater number of spikelets per plant observed for the $\mathrm{J}$ treatment also was due to more spikes per plant, as there was no difference in the mean number of spikelets per spike $(\approx 18)$ among $D$ and $J$ treatments. This was expected, since spikelet primordium initiation occurs from the double ridge stage to near the beginning of internode elongation, and the terminal spikelet has appeared well before jointing (Hay, 1986; Malvoisin, 1984; McMaster et al., 1992b).

The effects of irrigation treatment on the patterns of yield components are less evident in the 1988 treatments. In general, the plant yield component means for $\mathrm{A}$ and $\mathrm{J}+\mathrm{A}$ treatments were intermediate to those for the $\mathrm{D}$ and $\mathrm{J}$ treatments (Table 3). Significant block $\times$ treatment interaction prevented detecting statistical significance in comparing $A$ and $\mathrm{J}+\mathrm{A}$ treatments. Separate analysis showed that mean kernel weight increased from $24 \mathrm{mg}$ to $28 \mathrm{mg}$ and chaff weight per spike significantly increased $(P=0.03)$ from $302 \mathrm{mg}$ to $348 \mathrm{mg}$ with irrigation at anthesis. Irrigation at anthesis should have the greatest effect on grain set and kernel growth, since all developmental events leading to fully developed florets have already been completed. Kernel growth can be affected in various ways by irrigation. For example, irrigation should increase leaf longevity, thus prolonging leaf area duration into grain filling (Wilhelm et al., 1993), increasing the duration and rate of grain filling (Frank et al., 1987; McMaster and Smika, 1988; Singh et al., 1984; Sionit et al., 1980), and increasing peduncle elongation and storage of photoassimilates in the internode tissue (Apel and Natr, 1976; Rawson and Evans, 1971). The 1988 results clearly show that irrigation at anthesis increased kernel weight, but an effect on grain set was less evident. Given that 1988 was only slightly drier than the $30-y r$ norm, it is likely that water was not sufficiently limiting to significantly alter grain set, but was sufficiently less than optimal to affect grain weight. This result is consistent with Hsiao's (1973) finding that growth (cell expansion) is affected before development (cell division).

Considering data for all yield components for both years, it appears that the number of spikes per plant was the dominant factor in affecting yield (Table 3), as has been found in other studies where conditions were not considered optimal (e.g., Beuerlein et al., 1989; Blue et al., 1990; Tompkins et al., 1991). Many of the other yield components (such as spikelet number, kernel number, kernel weight, and chaff weight) are largely a function of the number of spikes. Both number of kernels per spike and average kernel weight are variables that showed little increase with irrigation. Therefore, increases in number of spikes with irrigation resulted in corresponding increases in other plant yield components.

The yield contribution by culm groups varied among treatments (Table 4). Secondary tillers contributed only

Table 3. Individual plant grain yield and yield components from four irrigation treatments.

\begin{tabular}{|c|c|c|c|c|c|c|c|c|}
\hline Treatment $\dagger$ & $\begin{array}{l}\text { Kernel } \\
\text { yield }\end{array}$ & $\begin{array}{c}\text { Spike } \\
\text { number }\end{array}$ & $\begin{array}{l}\text { Spikelet } \\
\text { number }\end{array}$ & $\begin{array}{l}\text { Kernel } \\
\text { number }\end{array}$ & $\begin{array}{l}\text { Kernel } \\
\text { number }\end{array}$ & $\begin{array}{l}\text { Kernel } \\
\text { weight }\end{array}$ & $\begin{array}{c}\text { GPLR } \$ \\
\text { wt. }\end{array}$ & $\begin{array}{l}\text { Rachis } \\
\text { wt. }\end{array}$ \\
\hline & g plant ${ }^{-1}$ & 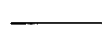 & no. plant & - & no. spike ${ }^{-1}$ & mg kernel ${ }^{-1}$ & g plant ${ }^{-1}$ & mg plant $^{-1}$ \\
\hline \multirow{2}{*}{\multicolumn{9}{|c|}{ Pooled over years }} \\
\hline & 4.6 & 5.1 & 94 & 174 & 34 & 26 & 1.4 & 120 \\
\hline $\mathbf{J}$ & 7.5 & 9.1 & 164 & 318 & 35 & 24 & 2.6 & 138 \\
\hline Probability & 0.09 & 0.03 & 0.05 & 0.04 & 0.18 & $\S$ & 0.06 & 0.33 \\
\hline \multicolumn{9}{|l|}{1988} \\
\hline A & 6.7 & 6.8 & 123.2 & 249 & 37 & 28 & 2.4 & 157 \\
\hline $\mathrm{J}+\mathrm{A}$ & 7.0 & 6.2 & 116.8 & 252 & 40 & 28 & 2.3 & 151 \\
\hline
\end{tabular}

$\dagger$ For both years, the dryland (D) and late jointing $(J)$ treatments are pooled; anthesis (A) and late jointing + anthesis $(\mathrm{J}+\mathrm{A})$ treatments are for 1988 data. Significant block $\times$ treatment interaction prevented detecting statistical significance in comparing $A$ and $J+A$ treatments.

$\$$ GPLR = glumes, paleas, lemmas, and rachillas.

$\S$ Significant year $\times$ treatment interaction. 
Table 4. Contribution of culm groups to plant yield.

\begin{tabular}{|c|c|c|c|c|c|c|c|c|}
\hline \multirow{3}{*}{$\begin{array}{l}\text { Tiller } \\
\text { group }\end{array}$} & \multicolumn{8}{|c|}{ Treatment $\dagger$} \\
\hline & \multicolumn{4}{|c|}{ Yield contribution } & \multicolumn{4}{|c|}{ Kernel yield } \\
\hline & D & $\mathbf{J}$ & A & $\mathbf{J}+\mathbf{A}$ & D & $\mathbf{I}$ & $\mathbf{A}$ & $\mathbf{J}+\mathbf{A}$ \\
\hline & \multicolumn{4}{|c|}{$-\%$} & \multicolumn{4}{|c|}{ g kernels plant ${ }^{-1}$} \\
\hline $\begin{array}{l}\text { Primary } \\
\text { Secondary }\end{array}$ & $\begin{array}{r}92 \\
8\end{array}$ & $\begin{array}{l}82 \\
18\end{array}$ & $\begin{array}{l}86 \\
14\end{array}$ & $\begin{array}{l}83 \\
17\end{array}$ & $\begin{array}{l}4.2 \\
0.4\end{array}$ & $\begin{array}{l}6.2 \\
1.3\end{array}$ & $\begin{array}{l}5.8 \\
0.9\end{array}$ & $\begin{array}{l}5.8 \\
1.2\end{array}$ \\
\hline Total & 100 & 100 & 100 & 100 & 4.6 & 7.5 & 6.7 & 7.0 \\
\hline
\end{tabular}

† The dryland (D) control and late jointing $(J)$ irrigation treatments combine both years of data; the anthesis (A) and late jointing + anthesis $(\mathrm{J}+\mathrm{A})$ irrigation treatments are for 1988 only. Main stems are included with the primary tillers. No tertiary tillers produced kernels.

$8 \%$ to the total yield in the dryland treatment, whereas irrigation doubled the contribution of secondary tillers to total yield. No tertiary tillers produced spikes, although tertiary tillers did appear, particularly in the irrigated treatments. The added contribution by secondary tillers was at no cost to the primary tillers, since the primary tiller weight increased for irrigated treatments.

The increase in contribution of secondary tillers to total plant yield with irrigation could be due to greater tillering, fewer tillers aborting, or proportionally greater spike weights. The tillering period normally is completed by jointing (Darwinkel, 1978; Kirby, 1985; McMaster et al., 1992b), and therefore greater tillering cannot be the cause, because the first irrigation at late jointing occurred after the tillering period. The weighted mean spike weight of secondary tillers was $375,394,372$, and $619 \mathrm{mg} \mathrm{spike}^{-1}$, for $\mathrm{D}, \mathrm{J}, \mathrm{A}$, and $\mathrm{J}+\mathrm{A}$ treatments, respectively. The mean number of secondary spikes per plant was $1.0,3.3,2.5$, and 2.5 for $\mathrm{D}, \mathrm{J}, \mathrm{A}$, and $\mathrm{A}+\mathrm{J}$ treatments, respectively. Although irrigation tended to slightly increase the spike weight of all culms, clearly the increased contribution of secondary culms to total plant yield was due to more secondary spikes in irrigated treatments. Therefore, the primary factor must be greater secondary tiller abortion in the dryland treatment. Power and Alessi (1978) and Thorne and Wood (1988) found similar responses to $\mathrm{N}$ fertilizer.

If the contribution of specific culms to plant yield is examined (Table 5), the results are similar to that found when within culm groups (Table 4). The addition of more culms producing spikes on a plant under irrigation was not at the expense of other major yield-producing culms such as the MS, T1, and T2 culms. As previously mentioned, the increased contribution of secondary tillers was mostly due to more secondary tillers on the plant, not increased secondary spike weight. This was also true for later appearing primary tillers such as T3, T4, T5, and T6.

\section{CONCLUSIONS}

Grain yield is the result of many developmental and physiological events occurring throughout the life of the plant. As expected, irrigation improved wheat grain yield, but different components were affected, depending on the time of irrigation. For the conditions of this study, number of spikes per plant was the most important yield component determining final yield. Therefore, if only one irrigation event is possible, application near jointing is suggested to maximize the number of spikes per plant.
Table 5. Contribution of specific culms to total plant grain yield.

\begin{tabular}{|c|c|c|c|c|c|c|c|c|}
\hline \multirow[b]{3}{*}{ Stem ID $\ddagger$} & \multicolumn{8}{|c|}{ Treatment $\dagger$} \\
\hline & \multicolumn{4}{|c|}{ Yield contribution } & \multicolumn{4}{|c|}{ Mean weight } \\
\hline & D & $\mathbf{J}$ & A & $\mathbf{J}+\mathbf{A}$ & $\mathrm{D}$ & $\mathbf{J}$ & A & $\mathbf{J}+\mathbf{A}$ \\
\hline & & - & 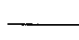 & 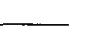 & $-\mathrm{m}_{\mathrm{r}}$ & g kerne & s culm & -1 \\
\hline MS & 29.0 & 18.5 & 21.0 & 20.3 & 1324 & 1379 & 1404 & 1425 \\
\hline $\begin{array}{l}\text { T0 } \\
\text { T00 } \\
\text { T01 } \\
\text { T02 }\end{array}$ & $\begin{array}{l}5.5 \\
0.2 \\
0.2 \\
-\end{array}$ & $\begin{array}{l}0.9 \\
0.5 \\
-\end{array}$ & $\begin{array}{l}- \\
- \\
\overline{0} .1\end{array}$ & $\begin{array}{l}1.0 \\
0.5 \\
1.0 \\
-\end{array}$ & $\begin{array}{r}250 \\
11 \\
-7 \\
-\end{array}$ & $\begin{array}{c}431 \\
69 \\
37 \\
-\end{array}$ & $\begin{array}{l}- \\
- \\
-\end{array}$ & $\begin{array}{r}74 \\
39 \\
71 \\
-\end{array}$ \\
\hline $\begin{array}{l}\text { T1 } \\
\text { T10 } \\
\text { T11 } \\
\text { T110 } \\
\text { T12 } \\
\text { T13 }\end{array}$ & $\begin{array}{c}20.2 \\
4.2 \\
0.6 \\
- \\
- \\
-\end{array}$ & $\begin{array}{r}15.4 \\
4.4 \\
3.4 \\
0.0 \\
0.5 \\
0.1\end{array}$ & $\begin{array}{r}16.1 \\
3.9 \\
2.5 \\
\overline{0} .5 \\
-\end{array}$ & $\begin{array}{r}17.7 \\
3.6 \\
4.7 \\
- \\
0.6 \\
0.5\end{array}$ & $\begin{array}{c}925 \\
192 \\
27 \\
- \\
- \\
-\end{array}$ & $\begin{array}{r}1146 \\
330 \\
250 \\
0 \\
37 \\
5\end{array}$ & $\begin{array}{c}1079 \\
263 \\
165 \\
- \\
35 \\
-\end{array}$ & $\begin{array}{r}1246 \\
254 \\
328 \\
- \\
45 \\
32\end{array}$ \\
\hline $\begin{array}{l}\text { T2 } \\
\text { T20 } \\
\text { T200 } \\
\text { T21 } \\
\text { T22 } \\
\text { T220 }\end{array}$ & $\begin{array}{c}19.2 \\
2.3 \\
- \\
0.7 \\
0.0 \\
-\end{array}$ & $\begin{array}{r}14.9 \\
3.3 \\
0.0 \\
1.8 \\
0.4 \\
-\end{array}$ & $\begin{array}{r}22.3 \\
3.1 \\
\overline{2} .5 \\
0.5 \\
0.0\end{array}$ & $\begin{array}{c}15.7 \\
1.3 \\
\overline{1.8} \\
0.0 \\
-\end{array}$ & $\begin{array}{c}876 \\
107 \\
- \\
32 \\
0 \\
-\end{array}$ & $\begin{array}{r}1115 \\
250 \\
0 \\
134 \\
29 \\
-\end{array}$ & $\begin{array}{r}1492 \\
207 \\
- \\
169 \\
38 \\
0\end{array}$ & $\begin{array}{r}1108 \\
91 \\
- \\
129 \\
0 \\
-\end{array}$ \\
\hline $\begin{array}{l}\text { T3 } \\
\text { T30 } \\
\text { T31 } \\
\text { T32 }\end{array}$ & $\begin{array}{c}11.9 \\
0.0 \\
- \\
-\end{array}$ & $\begin{array}{r}11.9 \\
0.7 \\
0.8 \\
0.1\end{array}$ & $\begin{array}{r}10.6 \\
0.1 \\
0.6 \\
-\end{array}$ & $\begin{array}{c}14.1 \\
1.1 \\
1.0 \\
-\end{array}$ & $\begin{array}{r}543 \\
0 \\
- \\
-\end{array}$ & $\begin{array}{r}891 \\
49 \\
62 \\
11\end{array}$ & $\begin{array}{r}707 \\
5 \\
38 \\
-\quad\end{array}$ & $\begin{array}{r}993 \\
78 \\
68 \\
-\end{array}$ \\
\hline $\begin{array}{l}\text { T4 } \\
\text { T40 } \\
\text { T41 }\end{array}$ & $\begin{array}{l}4.3 \\
- \\
-\end{array}$ & $\begin{array}{l}9.8 \\
0.4 \\
0.0\end{array}$ & $\begin{array}{l}9.2 \\
0.2 \\
-\end{array}$ & $\begin{array}{c}7.9 \\
0.0 \\
-\end{array}$ & $\begin{array}{l}195 \\
- \\
-\end{array}$ & $\begin{array}{r}732 \\
28 \\
0\end{array}$ & $\begin{array}{c}614 \\
12 \\
-\end{array}$ & 556 \\
\hline $\begin{array}{l}\text { T5 } \\
\text { T50 } \\
\text { T51 }\end{array}$ & $\begin{array}{l}1.2 \\
- \\
-\end{array}$ & $\begin{array}{l}4.3 \\
0.2 \\
0.1\end{array}$ & $\begin{array}{l}5.2 \\
0.0 \\
-\end{array}$ & $\begin{array}{l}5.6 \\
0.6 \\
-\end{array}$ & $\begin{array}{l}57 \\
- \\
-\end{array}$ & $\begin{array}{r}323 \\
12 \\
11\end{array}$ & $\begin{array}{r}351 \\
0 \\
-\quad\end{array}$ & $\begin{array}{r}392 \\
41 \\
-\end{array}$ \\
\hline T6 & 0.2 & 1.5 & 1.7 & 1.0 & 10 & 115 & 117 & 67 \\
\hline T7 & 0.3 & 0.2 & - & - & 15 & 17 & - & - \\
\hline Total & 100.0 & 100.0 & 100.0 & 100.0 & 4571 & 7467 & 6696 & 7037 \\
\hline
\end{tabular}

$\dagger$ Data from 1987 and 1988 are pooled for the dryland (D) and late jointing (J) treatments and data for anthesis (A) and late jointing + anthesis $(\mathrm{J}+\mathrm{A})$ treatments are from 1988 only.

¥ Naming scheme is according to Klepper et al. (1983). Plants within treatments that had specific tillers appear but did not produce kernels are denoted with zeros, otherwise dashes are used to denote that tillers did not appear.

This also suggests that water stress near jointing is a critical limitation to final yield production in the Central Great Plains by reducing the number of secondary tiller spikes and later-appearing primary tiller spikes.

\section{ACKNOWLEDGMENTS}

Appreciation is extended to $G$. Richardson for help in the statistical analysis, and J. Morgan, B. Weaver, D. LeCain, and D. Christensen for assistance throughout the project.

\section{REFERENCES}

Apel, P., and L. Natr. 1976. Carbohydrate content and grain growth in wheat and barley. Biochem. Physiol. Pflanz. 169:437-446.

Baker, C.K., and J.N. Gallagher, 1983. The development of winter wheat in the field: I. Relation between apical development and plant morphology within and between seasons. J. Agric. Sci. (Cambridge) 101:327-335.

Barnard, C. 1955. Histogenesis of the inflorescence and flower of Triticum aestivum L. Aust. J. Bot. 3:1-24.

Bauer, A., D. Smika, and A. Black. 1983. Correlation of five wheat growth stage scales used in the Great Plains. USDA AAT-NC-7.

Beuerlein, J.E., E.S. Oplinger, and D. Reicosky. 1989. Yield and yield components of winter wheat cultivars as influenced by management. J. Prod. Agric. 2:257-261.

Blue, E.N., S.C. Mason, and D.H. Sander. 1990. Influence of planting 
date, seeding rate, and phosphorus rate on wheat yield. Agron. J. 82:762-768

Darwinkel, A. 1978. Patterns of tillering and grain production of winter wheat at a wide range of plant densities. Neth. J. Agric. Sci. 26: 383-398.

Eck, H.V. 1988. Winter wheat response to nitrogen and irrigation. Agron. J. $80: 902-908$.

Fisher, J.E. 1973. Developmental morphology of the inflorescence in hexaploid wheat cultivars with and without the cultivar Norin 10 in their ancestry. Can. J. Plant Sci. 53:7-15.

Frank, A.B., A. Bauer, and A. Black. 1987. Effects of air temperature and water stress on apex development in spring wheat. Crop Sci. 27:113-116.

Hay, R.K.M. 1986. Sowing date and the relationships between plant and apex development in winter cereals. Field Crops Res. 14:321-337.

Hsiao, T.C. 1973. Plant responses to water stress. Annu. Rev. Plant Physiol. 24:519-570.

Kirby, E.J.M. 1985. Significant stages of ear development in winter wheat. p. 7-24. In W. Day and R.K. Atkin (ed.) Wheat growth and modeling. Plenum Press, New York.

Klepper, B., R.W. Rickman, and R.K. Belford. 1983. Leaf and tiller identification on wheat plants. Crop Sci. 23:1002-1004.

Malvoisin, P. 1984. Organogenesis and growth of the main culm of wheat from sowing to flowering: I. Relationships between leaf growth and the differentiation of young leaves of flowers. Agronomie (Paris) 4:557-564

McMaster, G.S., and D.E. Smika. 1988. Estimation and evaluation of winter wheat phenology in the Central Great Plains. Agric. For. Meteorol. 43:1-18.

McMaster, G.S., B. Klepper, R.W. Rickman, W.W. Wilhelm, and W.O. Willis. 1991. Simulation of shoot vegetative development and growth of unstressed winter wheat. Ecol. Modell. 53:189-204.

McMaster, G.S., J.A. Morgan, and W.W. Wilhelm. 1992a. Simulating winter wheat spike development and growth. Agric. For. Meteorol. 60:193-220.

McMaster, G.S., W.W. Wilhelm, and J.A. Morgan. 1992b. Simulating winter wheat shoot apex phenology. J. Agric. Sci. (Cambridge) 119:1-12.

Musick, J.T., and D.A. Dusek. 1980. Planting date and water deficit effects on development and yield of irrigated winter wheat. Agron. J. $72: 45-52$.

Power, J.F., and J. Alessi. 1978. Tiller development and yield of standard and semidwarf spring wheat varieties as affected by nitrogen fertilizer. J. Agric. Sci. (Cambridge) 90:97-108.

Rawson, H.M., and L.T. Evans. 1971. The contribution of stem reserves to grain development in a range of cultivars of different height. Aust. J. Agric. Res. 22:851-863.

SAS Institute. 1991. SAS language and procedures. Version 6.0. SAS Inst., Cary NC.

Singh, N.T., G.C. Aggarwal, and G.S. Brar. 1984. Effect of soil-moisture stress on heat-unit requirement of wheat at maturity. Indian J. Agric. Sci. 54:442-444.

Sionit, N., I.D. Teare, and P.J. Kramer. 1980. Effects of repeated application of water stress on water status and growth of wheat. Physiol. Plant. 50:11-15.

Thorne, G.N., and D.W. Wood. 1988. Contributions of shoot categories to growth and yield of winter wheat. J. Agric. Sci. (Cambridge) 111:285-294.

Tompkins, D.K., G.E. Hultgreen, A.T. Wright, and D.B. Fowler. 1991. Seed rate and row spacing of no-till winter wheat. Agron. J. 83: 684-689.

Unger, P.W., and T.M. McCalla. 1980. Conservation tillage systems. Adv. Agron. 33:1-58.

Wilhelm, W.W., H. Bouzerzour, and J.F. Power. 1989. Soil disturbance-residue management effect on winter wheat growth and yield. Agron. J. 81:581-588.

Wilhelın, W.W., G.S. McMaster, R.W. Rickman, and B. Klepper. 1993. Above ground vegetative development and growth of winter wheat as influenced by nitrogen and water availability. Ecol. Modell. 68: 183-203.

Zadoks, J.C., T.T. Chang, and C.F. Konzak. 1974. A decimal code for the growth stages of cereals. Weed Res. 14:415-421. 